\title{
PEMBERDAYAAN MASYARAKAT DENGAN PEMBUATAN PAKAN TERNAK JERAMI FERMENTASI DI DESA PUCAKWANGI KECAMATAN BABAT KABUPATEN LAMONGAN
}

\author{
Pudyartono, dan Martha Laila Arisandr \\ Universitas Islam Darul Ulum Lamongan \\ Jl. Airlangga No. 03 Sukodadi-Lamongan
}

\begin{abstract}
ABSTRAK
Limbah pertanian pada saat panen cukup banyak bahkan melimbah namun pemanfaatannya belum dilaksanakan secara optimal guna menunjang kebutuhan masyarakat oleh karena itu dilaksanakan kegiatan pemberdayaan masyrakat dengan pembuatan pakan ternak jerami fermentasi, mitra peternak di Desa Pucakwangi Kecamatan abat Kabupaten Lamongan. Metode yang pendekatan yang digunakan sosialisasi program, penyuluhan, pelatihan secara teori dan praktek, serta pendampingan dalam pembuatan pakan ternak jerami fermentasi. Hasil kegiatan menunjukkan bahwa pakan ternak jerami fermentasi sangat berguna untuk mengatasi pakan ternak utamanya pada musim kemarau dan hasil uji coba ternak sangat menyukai pakan fermentasi dibanding pakan tanpa fermentasi, sedangkan kegiatanm penyuluhan dan pelatihan berjalan secara baik dan bermanfaat untuk mewujudkan kemandirian pakan dengan memanfaatkan limbah pertanian potensi local. Kegiatan pendampingan masih diperlukan untuk keberlanjutan program. Pakan ternak jerami fermentasi mempunyai nilai nutrisi lebih baik dan lebih disukai ternak sehingga dapat meningkatkan produksi ternak dari bertambahnya bobot badan ternak.
\end{abstract}

Kata Kunci : Pemberdayaan, Limbah pertanian, Pakan ternak, Fermentasi.

\section{PENDAHULUAN}

Perberdayaan masyarakat merupakan salah satu metode dalam rangka menggerakkan jalannya pembangunan masyarakat baik dalam aspekekonomi, social budaya, pendidikan, kesehatan. Untuk mewujudkannya pemberdayaan yang merupakan salah satu pilar dalam penguatan otonomi daerah secara spesifik maka harus dimulai dari lingkungan terkecil dari komunitas masyarakat yaitu desa. Oleh karena itu sangat diperlukan fasilitasi oleh pemerintah dan seluruh stakeholders pemberdayaan masyarakat, termasuk perguruan tinggi.

Pembuatan pakan ternak fermentasi merupakan salah satu kegiatan pemberdayaan masyarakat dalam rangka kegiatan pengabdian masyarakat KKN PPM dengan topok utamanya Pemberdayaan masyarakat dalam pembuatan pupuk organic berbasis potensi local. Dilakukannya pembuatan pakan ternak fermentasi di desa tersebut tersedia jerami yang cukup banyak yang dapat digunakan sebagai pupuk organic dan dapat dimanfaatkan sebagai pakan ternak yang diolah secara fermentasi.

Berdasarkan data BPS Tahun 2016 Kabupatem Lamongan merupakan pemasok daging yang cukup memadai dengan populasi sebanyak 104.823 ekor sapi, sebanyak 185.645 ekor kambing, Kecamatan Babat sebanyak 3.557 ekor sapi dan 10.060 ekor kambing, sedangkan di Desa Pucakwangi populasi ternasebanyak 205 ekor sapid an 436 ekor kambing.

Upaya penyediaan daging yang cukup dapat dilakukan dengan peningkatan populasi dan disamping itu dapat dilakukan dengan peningkatan produksi daging dengan cara peningkatan pertambahan bobot badan. Sejalan hal tersebut maka manajemen usaha menjadikan salah satu kunci utama dalam usaha penggemukan ternak supaya pengelolaan dilakukan secara baik dan target peningkatan bobot badan ternak tercapai secara optimal. Oleh karena itu penyediaan pakan ternak berkualitas pada penggemukan ternak sangat penting karena dapat meningkatkan nilai ekonomis.

Potensi limbah pertanian di Kabupaten Lamongan cukup besar, luas areal tanam padi seluas 150.533 hektar, yang mana untuk wilayah Kecamatan Babat seluas 7.788 hektar, Desa Pucakwangi seluas 95 hektar (BPS dan Dinas Pertanian dan Kehutanan Kabupaten Lamongan 2016).

Pakan bagi ternak merupakan kebutuhan pokok yang harus tercukupi agar ternak dapat tumbuh dan berkembang secara baik, baik dalam jumlahnya (kuantitas) maupun kandungan nutrisi pakannya (kualitas). Dalam penyediaan pakan ternak di Desa Pucakwangi Kecamatan Babat Kabupaten Lamongan masih ada beberapa permasalahan antara lain : (a). Limbah pertanian/jerami pada saat panen cukup 
berlimpah cenderung kurang termanfaatkan, bahkan masih banyak yang dibakar. (b). pakan ternak masih mengandalkan pada hijauan. (c). pengetahuan masyarakat masih rendah tentang pakan ternak yang berkualitas. (d). teknologi pembuatan pakan ternak berkualitas masih kurang.

Tujuan pemberdayaan masyarakat di Desa Pucakwangi melalui stranfer teknologim pembuatan pakan ternak berkualitas dengan cara sebagai berikut (a) mengaplikasikan secara langsung terkait dengan pembuatan pakan ternak fermentasi, (b). pendampingan agar masyyarakat bisa secara mandiri melakukan pembuatan pakan ternak fermentasi.

\section{METODE PELAKSANAAN}

Kegiatan pemberdayaan

ini

dilaksanakan di Desa Pucakwangi Kecamatan Babat Kabupaten Lamongan, mulai pada akhir Juli sampai dengan September 2018. Adapun pelaksanaan bekerjasama dengan kelompok tani "Sumber Arum I "

Metode yang digunakan dalam pemberdayaan masyarakat (khususnya peternak) sebagi berikut : (a). Sosialisasi program KKN PPM ke perangkat desa dan tokoh masyarakat agar mengetahui kegiatan kegiatan yang akan dilaksanakan selama kegiatan KKN PPM. (b). Penyuluhan tentang manfaat pakan ternak ferrmentasi bagi ternak. (c). Pelatihan yang dilakukan dengan cara memberikan teori dan praktek pembuatan jerami fermentasi. (d). Pendampingan supaya kegiatan pembuatan pakan ternak fermentasi berlangsung secara baik pasca kegiatan pendampingan masyarakat diharapkan terus melaksanakan kegiatan pembuatan pakan ternak fermentasi. (e). Hasil pakan ternak fermentasi dicobakan ke ternak sapi, yang mana sapi sangat menyukai pakan ternak/jerami fermentasi dibanding jerami tanpa fermentasi. (f). Monitoring dan evaluasi, untuk menjamin keberlanjutan kegiatan.

\section{HASIL DAN PEMBAHASAN}

Kegiatan pemberdayaan masyarakat melalui pembuatan pakan ternak jerami fermentasi merupakan upaya pemecahan permasalahan yang ada di Desa Pucakwangi dengan melakukan kegiatan sebagai berikut :

1. Penyuluhan kepada masyarakat.

Kegiatan ini ditujukan kepada masyarakat luar agar masyarakat tahu, mau, dan mau melaksanakan kegiatan pemanfaatan limbah pertanian/jerami digunakan sebagai pakan ternak jerami fermentasi, dengan harapan jerami tidak sekedar hanya sebagai bahan pakan kering yang masih punya nilai nutrisi yang rendah, dan bahkan terabaikan pada saaat musim panen padi dimana petani masih cenderung membakar jerami saja.Namundari kegiatan ini jerami dapat ditingkatkan nilai pemanfaatannya sebagai pakan ternak fermentasi yang dapat menjadi nilai nutrisi tinggi dan jerani dapat dimanfaatkan sebagai pupuk organic yang dapat meningkatkan kesuburan tanah dan memperbaiki struktur tanah.

2. Pelatihan pembuatan pakan ternak jerami fermentasi.

Pelatihan merupakan kegiatan transfer teknolgi yang langsung dapat diketahui dan dipraktekan oleh masyarakat, dengan tujuan agar masyarakat meningkat pemgetahuannya, keterampilannya, dan mempunyai kemendirian supaya kegiatan terus menerus dilakukan secara baik. Pada saat melaksanakan pelatihan masyarakat tampak antusian mengikuti agar bisa membuat pakan ternak fermentasi secara mandiri, yang dianggap teknik pembuatannya sederhana.

Dalam fermentasi jerami digunakan probiotik yaitu larutan yang mengandung mikroorganisme (makluk hidup berukuran sangat kecil) yang berperan membantu proses yang bermanfaat bagi manusia. Sedangkan probiotik yang ditambahkan dalam rangsum pakan dapat mambuat mikroorganisme positif bekerja pada keadaan yang optimal, sehingga pakan akan lebih mudah dicerma dan diserap

3. Pendampingan

Kegiatan pendampingan ini dilakukan dalam ramngka mendorong masyarakat untuk tetap dan terus menerus melakukan kegiatan pembuatan pakan ternak jerami fermentasi secara mandiri. agar masyarakat

Adapun luaran dari kegiatan ini adalah sebagai berikut : (1). Limbah pertanian termanfaatkan sebagai pakan ternak fermentasi, teknologi ini dengan memanfaatkan jerami yang diberikan probiotik. (2). Produk pakan ternak fermentasi, dari kegiatan pelatihan dan praktek telah dihasilkan produk pakan ternak sebanyak $2.500 \mathrm{Kg}$, produksi pakan ternak fermentasi tersebut terus bertambah sejalan dengan tingkat kebutuhan peternak..(3). Hasil pakan ternak fermentasi setelah dicobakan pada ternak menunjukkan bahwa ternak lebih menyukai pakan ternak fermentasi jika disbanding dengan pakan ternak tanpa fermentasi. (4).Menanambah tingkat pengetahuan masyarakat tentang manfaat pakan ternak jerami fermentasi.

Proses pembuatan pakan ternak jerami 2 fermentasi sebagai berikut : 
Bahan yang perlu dipersiapkan :

- $1000 \mathrm{~kg}$ : jerami yang sudah kering.

- 20-25 Lt : molase / gula pasir yang dilarutkan.

- $2 \mathrm{~kg} \quad$ : Urea

- $3 \mathrm{Lt} \quad$ : Probiotik.

- 250-300 Lt : air untuk melarutkan probiotik dan molase/tetes.

Peralatan yang perlu dipersiapkan :

- Terpal plastic atau plastik.

- Alat pemotong/sabit atau sejenisnya atau bisa menggunakan mesin pencaca jerami.

- Ember, gembor, terpal plastik atau karung plastik.

Cara pembuatan pakan fermentasi jerami kering

- Jerami kering dipotong-potong dengan ukuran kurang lebih $25 \mathrm{~cm}$ ditumpuk sediakan terpal plastik.

- Larutkan bahan diatas dicampur menjadi satu sesuai dengan perbandingannya (campuran probiotik, molase dan air).
- Jerami padi yang sudah dipotong ditaruh diatas terpal sedikit demi sedikit sambil disiram Urea, larutan air, molase/tetes dan probiotik sesuai perbandingan diatas sampai merata dan jerami kelihatan basah.

- Setelah jerami benar-benar telah disiram rata dengan larutan tersebut, jerami ditutup ke dalam terpal atau plastic sedikit demi sedikit sambil diinjak-injak supaya padat. Setelah padat ditutup hingga rapat betul.

- Setelah 7 hari jerami fermentasi tersebut baru dapat di berikan pada ternak sesuai dengan kebutuhan, setiap pengambilan pakan ternak jerami fermentasi maka tempat penyimpanan supaya ditutup kembali dengan rapat, hal tersebut agar terhindar dari genangan air, dan terhindar dari terik matahari secara langsung dan air hujan.

Foto kegiatan :
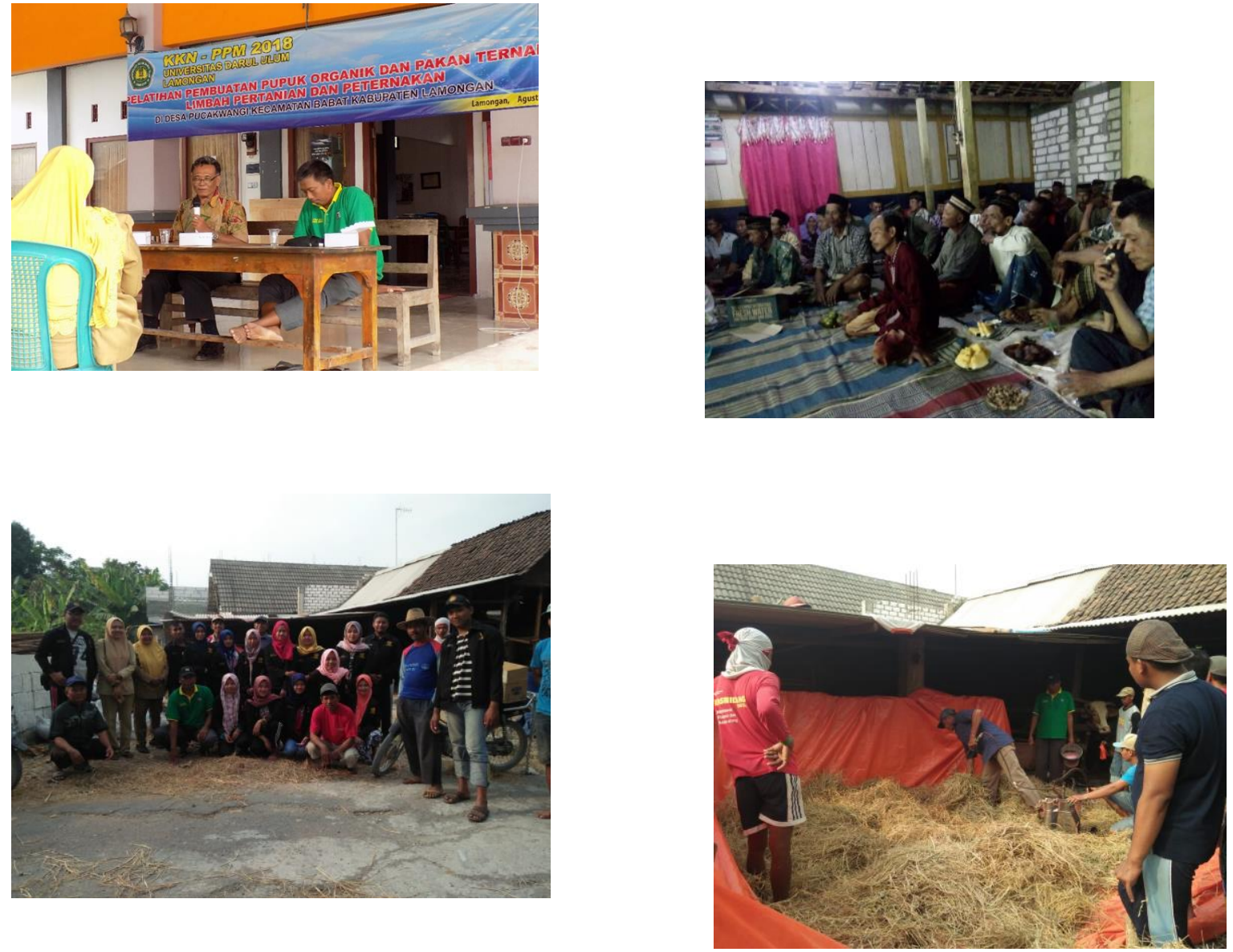


\section{KESIMPULAN}

Setalah dilaksanakan kegiatan ini maka masih diperlukan langkjah-langkah tindak lanjut. Sedangkan ntindak lanjut yang diperlukan diantaranya kegiatan pendampingan secara berkelanjutan kepada masyarakat di Desa Pucakwangi dalam upaya pengelolaan pakan ternak secara baik. Berdasarkan hasil kegiatan yang dilakukan dapat disimpulkan bahwa kegiatan pemberdayaan masyakaatan memberikan manfaat berupa peningkatan pengetahuan tentang nitrisi yang dibutuhkan ternak, pakan ternak yang bernutrisi tinggi, meningiatkan ketrampilan dalam pembuatan pakan ternak jerami fermentasi melalui kegiatan pelatihan baik teori maupun praktek. Untuk suksesnya program masih sangat diperlukan pendampingan secara kerkelanjutan baik oleh dinas teknis maupun lembaga lain. Dengan adanya kegiatan ini diharapkan dapat meningkatkan populasi ternakdan didukung bertambahnya bobot badan ternak yang lebih baik.

\section{UCAPAN TERIMA KASIH}

Atas terlaksananya program pengabdian kepada masyarakat KKN PPM tahun 2018 untuk itu kami mengucapkan terimakasih kepada DRPM Kementerian Riset, Teknologi dan Pendidikan Tinggi Rl atas didanainya kegiatan tersebut. Disamping itu kami juga mengucapkan terima kasih kepada Rektor Universitas Islam Darul Ulum Lamongan atas dukungan demi terselenggaranya kegiatan.

\section{DAFTAR PUSTAKA}

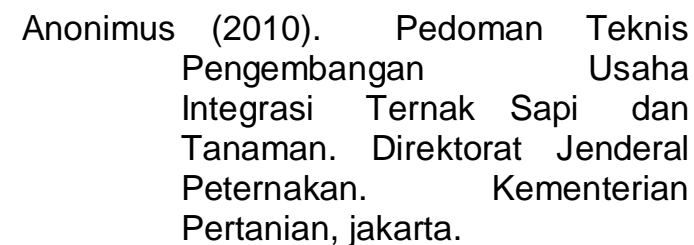

Anonimus (2016).Kabupaten Lamongan Dalam Angka 2016. Badan Pusat StatistikLamongan

Anonimus (2016) Kecamatan Babat Dalam Angka 2016. Badan Pusat Statistik. Lamongan

Yunilas. (2009). Karya IImiah. Bioteknologi Jerami Padi Melalui Fermentasi sebagai Bahan Pakan Ternak Ruminansia. Fakultas Pertanian, Universitas Sumatera Utara, Medan.

Parakkasi, A. (1999) Ilmu Makanan dan Ternak Ruminansia. Penerbit Universitas Indonesia, Jakarta 